Тетяна Кучай

Закарпатський угорський інститут ім. Ференца Ракоці II, м. Берегово ORCID ID 0000-0003-3518-2767

Олександр Кучай

Національний університет біоресурсів

і природокористування України

ORCID ID 0000-0002-9468-0486

DOI 10.24139/2312-5993/2020.03-04/049-056

\title{
ПРОФЕСІЙНА ПІДГОТОВКА ФАХІВЦІВ ЕКОНОМІЧНОГО ПРОФІЛЮ В УМОВАХ НЕПЕРЕРВНОÏ ОСВІТИ
}

У статті розкривається професійна підготовка фахівців економічного профрілю в умовах неперервної освіти. Виділено основні напрями неперервної освіти. Майбутні фахівці в галузі економіки мають бути здатними до реалізації проектної діяльності, кооперації та здорової конкуренції. Необхідний пошук таких форм організації навчальної діяльності майбутніх економістів у закладах вищої освіти, які забезпечували би їх практичними навичками соціальної взаємодії та сприяли розвиткові соціальних, моральних, особистісних якостей і професійної культури в цілому. Наголошується на тому, що формування професійної культури фрахівців економічного профрілю базується на загальних психолого-педагогічних принципах дидактики і виховання.

Ключові слова: професійна підготовка, фрахівці економічного профрілю, неперервна освіта, заклади вищої освіти.

Постановка проблеми. Неперервна освіта супроводжує процес зростання освітнього (загального і професійного) потенціалу особистості протягом життя, який організаційно забезпечений системою державних та суспільних інститутів і відповідає потребам особистості й суспільства.

Метою неперервної освіти $€$ становлення та розвиток особистості як у періоди ії фізичного і соціально-психологічного дозрівання, розквіту й стабілізації життєвих сил та здібностей, так і в періоди старіння організму, коли на перший план висувається завдання компенсації сил і можливостей, що втрачаються.

Системотвірним фактором неперервної освіти $€$ суспільна потреба в постійному розвиткові особистості кожної людини. Цим визначається впорядкування безлічі освітніх структур - основних і паралельних, базових і додаткових, державних і громадських (суспільних), формальних і неформальних. Їхній взаємозв'язок та взаємозумовленість, взаємна субординація за рівнями, координація за спрямованістю і призначенням, забезпечення взаємодії між ними перетворюють всю сукупність таких структур у єдину систему (Теорія і методика професійної освіти, 2012).

Період соціально-економічних трансформацій в Україні характеризується зміною низки колишніх суспільних цінностей і культурних 
стереотипів. Докорінна зміна традиційного способу життя породжує нові пріоритетні завдання сучасної освіти, а саме: навчання навчатися (вироблення вмінь оволодівати й оперувати найрізноманітнішою інформацією); навчання працювати (формування здатності ефективно оволодівати професійними навичками, уміння знаходити вихід у найнепередбачуваніших виробничих ситуаціях, співпрацювати в колективі, співвідносити себе з конкретними фаховими ролями й ефективно їх виконувати); навчання співіснувати (розвиток таланту до налагоджування соціальних відносин, виховання здатності до емпатії, персоніфікованих відносин з іншими людьми); навчання жити (формування цілісного світогляду, уміння бачити особистісний сенс життя, прагнути до духовної зрілості, бути відповідальним за себе та інших). Економічний підхід поширюється на все життя суспільства: головним економічним ресурсом стають інформація і знання, наростає боротьба економічних суб'єктів за інноваційний ресурс і випереджальний розвиток. Відповідно, цілі вищої економічної освіти мають передбачати не лише формування у випускників зВО певного комплексу фахових знань, умінь та навичок (які, до того ж, в умовах «інформаційного буму» швидко застарівають), але й розвиток творчої активності особистості та її здатності шукати і знаходити шляхи розв'язання проблем у мінливій економічній ситуації. Базовою цінністю суспільства, що трансформується, стає інноваційність - стан високої сприйнятливості людей до нових ідей, їхня готовність, бажання, здатність підтримувати й реалізовувати нововведення в усіх сферах своєї життєдіяльності. Цільовим орієнтиром діяльності сучасних 3 ВО у зв'язку з цим є формування в майбутніх фахівців (зокрема економістів), перш за все, інноваційного творчого мислення (Тувакова, 2013).

Актуальні дослідження і публікації. Теоретико-методологічні проблеми неперервної професійної освіти досліджували А. Алексюк, Р. Гуревич, М. Згуровський, В. Кремень, А. Лігоцький, Л. Лук'янова, В. Манько, Н. Ничкало, Л. Романишина, С. Сисоєва, Г. Терещук, В. Шахов та ін.

Мета дослідження - з'ясувати особливості професійної підготовки фахівців економічного профілю в умовах неперервної освіти.

Методи дослідження. Досягнення мети дослідження уможливило використання загальнотеоретичного методу наукового дослідження, зокрема аналізу термінологічного апарату психолого-педагогічних та соціально-філософських джерел наукового дискурсу.

Виклад основного матеріалу. Основою концепції розвитку неперервної освіти $€$ інноваційна педагогіка (розробка ефективних методів навчання впродовж життя i всеосяжного навчання, яке включає формальне, неформальне й позаформальне (спонтанне) навчання). Пріоритетним вектором освітніх процесів стає формування компетентності, розвиток знань і вмінь людей упродовж їх життя з тим, щоб вони могли 
досягати економічних і соціальних цілей за допомогою осмисленої поведінки.

Модель неперервної освіти $€$ багатокомпонентною, модульною і розгалуженою за трьома модулями (допрофесійне навчання, професійне навчання та навчання дорослих), що розкриваються основними ії складовими (родинно-сімейна, дошкільна, загальноосвітня, позашкільна, професійно-технічна, вища, післядипломна освіта); термінами життя людини (від народження до дорослого стану); різновидами освіти впродовж життя (формальна, неформальна, інформальна).

Поняття неперервності, покликане підсилити значущість поняття освіти, додати йому особливу доцільність, невипадковість, усвідомленість. Основний шлях одержання освіти - це навчання й самонавчання, тобто цілеспрямована діяльність, переосмислення навколишньої дійсності і свого місця в ній, самозбагачення, самопізнання, саморозвиток (Гулай, 2016).

Виділено основні напрями неперервної освіти:

- охоплення освітою всього життя людини;

- інтеграцію «вертикальну» (спадкоємність між окремими етапами та рівнями освіти) та «горизонтальну»;

- взаємозв'язок загальної та професійної освіти;

- відкритість, гнучкість системи освіти;

- різноманітність змісту, засобів і методик навчання та можливість вільного їх вибору;

- рівноправну оцінку й визнання освіти не по способах їі отримання, а по фактичному результату;

- наявність механізмів стимулювання мотивації особи до навчання як з боку матеріальних умов життя суспільства, так і через вплив культури та духовно-моральних цінностей.

Педагогічній концепції організації неперервності процесу навчання притаманна цілісність, сутність якої можна трактувати через такі поняття, як:

- спадкоємність (припускає поступовий перехід від одного освітнього ступеня до іншого, послідовність зміни вимог до обсягу знань, умінь і навичок на основі органічного зв'язку змісту, методів і форм навчальновиховного процесу);

- прогностичність (передбачає зорієнтованість освіти на перспективні запити і потреби як в матеріальній, так і в духовній сфері розвитку;

- сприяння професійному й особистому розвитку студентів не можливе без внесення своєчасних коректив у прогностичні моделі випускників, в ОKX, навчальні плани та програми з урахуванням педагогічного прогнозування);

- гнучкість та динамічність (пов'язані 3 ії відкритістю, багатоступінчастістю, різноманітністю існування всіх типів закладів освіти та форм навчально-пізнавальної діяльності) (Калаур, 2015). 
Актуальним завданням професійної підготовки фахівців економічного профілю в умовах неперервної освіти $€$ формування соціальних якостей суб'єктів навчання, у т. ч. і здатності до конструктивної соціальної взаємодії як складової частини їх загальної професійної культури. Майбутні фахівці в галузі економіки мають бути здатними до реалізації проектної діяльності, кооперації та здорової конкуренції. Необхідний пошук таких форм організації навчальної діяльності майбутніх економістів у закладах вищої освіти, які забезпечували б їх практичними навичками соціальної взаємодії та сприяли розвиткові соціальних, моральних, особистісних якостей і професійної культури в цілому.

Під час підготовки майбутніх економістів важливо розвивати й соціальні компетентності, адже у процесі здійснення професійної діяльності людина вступає у взаємодію з іншими учасниками виробничого процесу і тому повинна вміти координувати свої дії з діями інших, уміти працювати в команді, організовувати спільну діяльність, конструктивно вирішувати конфліктні ситуації тощо. Сьогодні ці якості стають важливими складовими частинами професійної культури майбутніх економістів (Саркісова, 2018).

Досягнення мети, завдань формування професійної культури фахівців економічного профілю базується на загальних психологопедагогічних принципах дидактики і виховання, зокрема:

- науковості - побудова процесу формування професійної культури в магістрантів-економістів на об'єктивно-істинних знаннях, вивчення найбільш вагомих наукових досягнень у професійній галузі, здобуття наукових знань, які створюють передумови для самовизначення студентів згідно з їх здібностями, інтересами, потребами;

- природовідповідності - врахування в роботі психологопедагогічних, індивідуально-типологічних особливостей особистості, багатогранної цілісної природи людини;

- культуровідповідності - органічний зв'язок з історією народу, його мовою, культурою, культурними традиціями, звичаями, обрядами, народним мистецтвом, ремеслами і промислами, забезпеченні духовної єдності, наступності і спадковості поколінь;

- гуманізації - можливість поставити особистість магістранта в центр уваги закладу вищої освіти, забезпечити умови для його творчого розвитку та активності;

- демократизації - співпраця, співтворчість педагога і студента, віра в його творчі сили, повага до суверенітету особистості;

- інтегрованості - єдність педагогічних вимог закладу вищої освіти, сім'ї й суспільства;

- пріоритету проблемно-розвивальної і творчої діяльності забезпечення розвитку інтелектуальної, емоційно-вольової та духовної сфер особистості; 
- сенситивності - урахування найбільш сприятливих періодів розвитку особистості для сприймання певного навчального матеріалу;

- психологізації педагогічного процесу закладу вищої освіти оволодіння кожним викладачем технологією діагностики і психодіагностики професійної культури особистості студента, корекції навчально-виховного процесу (Кушнір, 2018).

Проблема підготовки фахівців в умовах неперервності тісно поєднана з механізмом особистісного розвитку студентів, який передбачає самоспостереження, самоаналіз, особистісну психокорекцію. Запорукою успішного розвитку майбутнього фахівця є усвідомлення ним необхідності глибинного самопізнання, корекції та пошуків шляхів самовдосконалення.

Сутність, структура й функції культури виступають теоретичним підгрунтям для її формування в процесі професійної підготовки майбутніх фахівців, адже культурний досвід людства $€$ системою знань, умінь, форм діяльності і відносин, способів спілкування, конкретних зразків поведінки (Фільштейн \& Журавльов, 2016).

3 метою вдосконалення освітнього процесу закладів вищої освіти економічного профілю необхідно реалізувати комплексний підхід до професійної підготовки майбутніх фахівців. Значну роль у даному напрямі відіграє активізація пізнавальної діяльності майбутніх економістів, важливе місце в якій посідають нові форми та методи навчання, зокрема використання ділових ігор.

Активність студента в навчально-виховному процесі $\epsilon$ одним із провідних принципів дидактики вищої школи. Реалізація цього принципу передбачає таку якість навчальної діяльності, під час якої досягається високий рівень мотивації, усвідомлення необхідності засвоєння знань, умінь та навичок. Практика роботи нинішніх закладів вищої освіти переконує, що особливо важливу роль у навчальній діяльності відіграє індивідуальна робота студентів, пов'язана з дослідницькою діяльністю. Визначення готовності студентів не тільки вивчати фахові економічні дисципліни, але й залучати їх до проведення економічних досліджень як інтегрального особистісного утворення, що включає стійке прагнення до творчого наукового пошуку у сфері економіки, наявність спеціальних економічних знань і вмінь, а також комплексу індивідуально-психологічних і характерологічних особливостей, які забезпечують високу ефективність професійного функціонування.

Особистісний підхід в освітянському просторі припускає гуманістично орієнтоване навчання, де головною ниткою проходить ідея прагнення особистості до реалізації власних можливостей, потреби в їх розвитку. При цьому провідними в процесі самореалізації особистості $€$ внутрішні мотиви. Дійсно, можна володіти необхідними здібностями, перетворювальними знаннями й уміннями, але ніколи ними не 
користуватися через відсутність бажання і потреби в цьому. Тому, саме мотиви, органічно пов'язані зі змістом або процесом діяльності, забезпечують ту невпинну увагу, цікавість до неї, які призводять до розвитку відповідних здібностей (Вітер, 2012).

Висновки дослідження і перспективи подальших розвідок у цьому напрямі. Становлення економічної культури фахівців в умовах неперервної освіти повинно опиратися на ідеологію та морально-етичні принципи, що призведе до економічного оздоровлення й оновлення підприємств, установ та суспільства загалом із метою вироблення відповідної культури господарювання.

Неперервна освіта фахівців економічного профілю $є$ складовою вищої освіти і спрямована на підвищення ефективності підприємницької діяльності. Для ії раціонального функціонування необхідне підвищення професійного й морального рівня суб'єктів підприємництва, щоб забезпечити ефективну та якісну організаційну й управлінську діяльність.

При цьому необхідно поєднувати високу професійну компетентність із умінням організувати справу, бути достатньо діловими, перспективно мислячими, енергійними, наполегливими й ініціативними в роботі, оскільки від підприємців очікують високої громадянської зрілості, глибоких фахових знань, здатності забезпечити предметність, конкретність і оперативність в організації та управлінні, тобто високого професіоналізму (Кицкай, 2007).

\section{ЛITЕРАТУРА}

Курлянд, 3. Н. (Ред.) (2012). Теорія і методика профресійної освіти. К.: Знання (Kurland, Z. N. (Ed.) (2012). Theory and methods of professional education. K.: Znannia).

Гулай, О. І. (2016). Теоретико-методичні основи професійної підготовки майбутніх фахівців будівельного профрілю в умовах неперервної освіти (дис. ... д-ра пед. наук: 13.00.04). Вінниця (Hulai, О. І. (2016). Theoretical and methodological foundations of professional training of future specialists in construction in terms of continuing education (DSc thesis). Vinnytsia).

Калаур, С. М. (2015). Педагогічна концепція організації неперервності освіти майбутніх фахівців соціальної сфери. Науковий вісник Ужгородського національного університету. Серія: Педагогіка. Соціальна робота, 36, 71-74 (Kalaur, S. M. (2015). Pedagogical concept of continuing education of future professionals in the social sphere. Scientific Bulletin of Uzhhorod National University. Series: Pedagogy. Social work, 36, 71-74).

Саркісова, О. Ю. (2018). Групова взаємодія як чинник розвитку професійної культури майбутніх економістів. Науковий часопис НПУ імені М. П. Драгоманова, 62, 177180 (Sarkisova, O. Yu. (2018). Group interaction as a factor in the development of professional culture of future economists. Scientific journal of Drahomanov NPU, 62, 177-180).

Кушнір, Н. С. (2018). Теоретичний аспект формування професійної культури магістрантів економічного профілю. Вісник Чернігівського начіонального педагогічного 
університету ім. Т.Г. Шевченка, 150, 85-87 (Kushnir, N. S. (2018). Theoretical aspect of the formation of professional culture of masters of economic profile. Bulletin of Taras Shevchenko National Pedagogical University, 150, 85-87).

Фільштейн, Л. М., Журавльов, В. М. (2016). Професійна культура в аспекті підготовки фахівців. Наукові праці Кіровоградського начіонального технічного університету. Економічні науки, 29, 12-18 (Filstein, L. M., Zhuravlev, V. M. (2016). Professional culture in terms of training. Scientific works of Kirovograd National Technical University. Economic sciences, 29, 12-18).

Кицкай, Л. І. (2007). Економічна культура як складова економічної освіти. Режим доступу: http://novyn.kpi.ua/2007-3-2/09 Kickai.pdf (Kytskai, L. I. (2007). Economic culture as a component of economic education. Retrieved from: http://novyn.kpi.ua/2007-3-2/09 Kickai.pdf).

Вітер, С. (2012). Вимоги до майбутніх фахівців економічного профілю та якості їх професійної підготовки в умовах сьогодення. Молодь і ринок, 4, 149-153 (Viter, S. (2012). Requirements for future economic professionals and the quality of their training in today's conditions. Youth and market, 4, 149-153).

Тувакова, Н. В. (2013). Ключові аспекти фахової підготовки майбутніх економістів. Соціально-економічні проблеми сучасного періоду України, 1, 567-573 (Tuvakova, N. V. (2013). Key aspects of professional training of future economists. Socioeconomic problems of the modern period of Ukraine, 1, 567-573).

\section{PEЗЮME}

Кучай Татьяна, Кучай Александр. Профессиональная подготовка специалистов экономического профиля в условиях непрерывного образования.

В статье раскрывается профессиональная подготовка специалистов экономического профиля в условиях непрерывного образования. Выделены основные направления непрерывного образования. Будущие специалисты в области экономики должны быть способными к реализации проектной деятельности, кооперации и здоровой конкуренции. Необходим поиск таких форм организации учебной деятельности будущих экономистов в учреждениях высшего образования, которые обеспечивали бы их практическими навыками социального взаимодействия и способствовали развитию сочиальных, нравственных, личностных качеств и профессиональной культуры в целом. Подчеркивается, что формирование профессиональной культуры специалистов экономического профиля базируется на общих психолого-педагогических принципах дидактики и воспитания.

Ключевые слова: профессиональная подготовка, спечиалисты экономического профиля, непрерывное образование, высшие учебные заведения.

\section{SUMMARY}

Kuchai Tetiana, Kudhai Olexander. Professional training of economic profile specialists in conditions of continuing education.

The article reveals professional training of economic specialists in the context of continuing education. The main directions of continuing education are highlighted. Future specialists in the field of economics must be able to implement project activities, cooperation and healthy competition. It is necessary to find such forms of organization of educational activities of future economists in higher education institutions, which would provide them with practical skills of social interaction and promote the development of social, moral, personal qualities and professional culture in general.

It is emphasized that formation of professional culture of economic professionals is based on the general psychological and pedagogical principles of didactics and education. 
Formation of economic culture of specialists in the context of continuing education should be based on ideology and moral and ethical principles, which will lead to economic recovery and renewal of enterprises, institutions and society as a whole in order to develop an appropriate culture of management.

Continuing education of economic specialists is a component of higher education and is aimed at improving the efficiency of entrepreneurial activity. For its rational functioning it is necessary to raise the professional and moral level of business entities to ensure effective and high-quality organizational and managerial activities.

It is necessary to combine high professional competence with the ability to organize business, be businesslike, forward-thinking, energetic, persistent and proactive in work, as entrepreneurs are expected to have high civic maturity, deep professional knowledge, ability to provide subjectivity, specificity and efficiency in organization and management, i.e. high professionalism.

Key words professional training, economic specialists, continuing education, higher education institutions.

\section{удк 796:[378:37.011.3-051]}

Єлизавета Кучерган

Криворізький державний педагогічний університет

ORCID ID 0000-0003-0284-4349

DOI 10.24139/2312-5993/2020.03-04/056-066

\section{ФІЗИЧНЕ САМОВИХОВАННЯ СТУДЕНТІВ ЯК СКЛАДОВА СИСТЕМИ ПРОФЕСІЙНОГО ЗДОРОВ'Я МАЙБУТНЬОГО ВЧИТЕЛЯ}

Стаття присвячена дослідженню самовиховання фізичної культури студентів як складової частини профресійного здоров'я молодих учителів у системі, їх подальшої педагогічної діяльності. Збереження професійного здоров'я молодого вчителя, його адаптації до сучасних умов освітніх прочесів, залежить від якісного й системного виконання комплексу фізкультурно-оздоровчих вправ, які входять у навчальні програми з фізичного виховання студентів у ВНЗ, що здатні підтримувати їхнє здоров'я в майбутньому.

Збереження здоров'я вчителя за допомогою фрізичного самовиховання в середній школі та в подальшій професійній діяльності можливе лише у процесі взаємодії вчителя фрізичної культури з педагогічним колективом, де вчитель фрізичної культури виступає як наставник і тренер своїх колег.

Ключові слова: здоров'я, професійне здоров'я вчителя, професійне здоров'я вчителя фрізичної культури, профресійне здоров'я вчителів інших навчальних предметів, система взаємодії вчителя фрізичної культури та вчителів інших навчальних предметів, індивідуальне фізичне самовиховання, педагогічний колектив, фізичне самовиховання педагогічного колективу, освітні процеси збереження здоров'я вчителя, освітнє середовище.

Постановка проблеми. Швидкий розвиток технологічного прогресу все більше актуалізує проблеми, що пов'язані з професійним вигоранням вчителя. Сучасний стан освітніх процесів, закладів вищої і середньої освіти можливо схарактеризувати як активне впровадження інноваційних педагогічних технологій, що вимагають від майбутніх учителів фізичної культури не тільки підвищення професійних знань, умінь і навичок своєї 